\title{
Utajená skladba Janáčkova politického vzdoru. Ke genezi a recepci "slovanské rapsodie" Taras Bulba
}

\section{Janáček's Secret Expression of Political Defiance. Genesis and Reception of the "Slavonic rhapsody" Taras Bulba}

Jiří Zahrádka / jiri.zahradka@seznam.cz

Department of Musicology, Faculty of Arts, Masaryk University, Brno, CZ / Department of the History of Music, Moravian Museum, Brno, CZ

\begin{abstract}
The "Slavonic rhapsody" Taras Bulba is an example of Janáček's lifelong Russophilia. The composer adhered to the Russian culture through the declared Slavic patriotism in his early youth, all this being closely connected with the feelings of liberation of the nation and the question of Pan-Slavism. Janáček read the Russian original of Gogol's novel Taras Bulba in 1905 in the Brno-based Russian Circle. He then returned to this theme at the beginning of the WW1 when he got horrified by the fact that Slavic nations are fighting each other. As an expression of protest against this fact Janáček began to compose the "Slavonic rhapsody" Taras Bulba in January 1915.
\end{abstract}

The work was completed by the beginning of July and Janáček then had it copied by the copyist Vojtěch Ševčík. The rhapsody wasn't, however, taken any further, no attempts to get it performed were made and even the title itself was kept secret. The reason was the high political tension in the empire: for instance a ban was imposed on the Russian Circle and Janáček as its head had to negotiate its liquidation with the police headquarters. Furthermore, Janáček's friend, the poet Petr Bezruč, was arrested and accused of treason for the alleged eulogizing poems about the tsar and Russian army published abroad. It is no surprise that Janáček got worried. He resumed work on Taras only after the premiere of Jenưfa in the Viennese Hofoper: in March 1918 he made a thorough revision and had the reworked parts copied by Václav Sedláček. The first performance, conducted by František Neumann, took place in Brno on 9 October 1921. Neumann worked out a detailed dynamics and made some changes. At this stage another copy was made, again by Vojtěch Ševčík. Subsequent performance was in Brno again, on 21 January 1924, again conducted by František Neumann, from the original 1918 copy of the score. Then followed a Prague performance on 9 November 1924 by the Czech Philharmonic 
Orchestra conducted by Václav Talich. He already used the new 1922 copy of the score and made some changes that were approved by the composer in person.

Then began the negotiations of publication. Universal Edition in Vienna refused the composition on political grounds so it was finally published by Hudební matice Umělecké besedy in Prague. First the four-hand piano arrangement by Břetislav Bakala was published in 1925 (based on the 1922 score). Hudební matice then showed some reluctance concerning the publication of the score and performing materials. Just the confusing handwritten performing materials were offered with inscribed alterations from previous performances, not corresponding to the 1917 copy of the score. This was also the reason why in 1926 and 1927 the proposed performances in London, Paris and Zagreb were called off.

Janáček then decided to notify Hudební matice of his withdrawal of Taras from them. This threat, however, forced the publisher to take steps towards prompt publication. Before that, in June 1927, Janáček revised the work once more significantly. The score was published in December 1927. Thanks to the preserved autograph and copies we can follow the development of this remarkable work in detail. This text is published as a preliminary study for the critical edition of Taras Bulba that will be published in 2018.

\section{Keywords}

Taras Bulba, Leoš Janáček, genesis of the work, orchestra, Russophilia, rhapsody, Slavism, Editions

Rapsodie pro orchestr Taras Bulba je nejvýznamnější a svou genezí nejzajímavější ze tří symfonických programních skladeb, které skladatel napsal v nedlouhém období mezi léty 1914-1920. Jsou to kompozice, které reagují na dobový kontext sociální i politický (Šumařovo dítě - sociální obžaloba, Taras Bulba - reakce na světový válečný konflikt, Balada Blanická - reflektuje vznik Československa). Janáčkovi, bytostnému dramatikovi, programní hudba spojená s mimohudebním obsahem, velmi konvenovala. Skladatel měl potřebu vyprávět příběh a to v celém spektru své tvorby; v sólových skladbách (Po zarostlém chodnícku, 1. X. 1905 „Z ulice“), v komorních kompozicích (Pohádka, oba smyčcové kvartety, dokonce i Capriccio) i v orchestrálních skladbách. Vedle Šumařova dítěte, Tarase Bulby a Balady blanické nalézáme děj i v Žárlivosti (Úvodu k Jeji pastorkyni), náznak příběhu je přítomen i ve fragmentu symfonie Dunaj, houslovém koncertu „Putováni dušičky“ a Janáček mimohudební obsah ex post přidal dokonce i k Sinfoniettě.

\section{Janáčkovo rusofilství a Taras Bulba}

Dalším důležitým znakem Tarase Bulby je, že patři do početné skupiny kompozic, jejichž námět Janáček čerpal z ruské literatury. Janáčkův vztah k ruské kultuře a jazyku se utvářel postupně a skrze slovanství. Panslavizmus je velké téma celého 19. století a Janáček, jako mnohý intelektuál té doby, jím byl silně ovlivněn. Na jeho společensky 
deklarované slovanství mělo jistě vliv prostředí, ve kterém vyrůstal. Na jedné straně majoritně německé obyvatelstvo Brna a na straně druhé augustiniánský klášter na Starém Brně, místo jeho nedobrovolného pobytu v letech dětství a dospívání, které bylo výrazně slovansky orientované. Janáček zde zažil především silný cyrilometodějský kult, který byl pochopitelně prodchnut národně-obrozeneckými aktivitami. Sám prelát Cyril Napp (1792-1867) byl členem výboru Matice velehradské a aktivně se podílel v roce 1863 na oslavách 1000letého výročí příchodu sv. Cyrila a Metoděje na Moravu. Také Janáčkův učitel, ředitel fundace, kněz Pavel Křrižkovský (1820-1885), měl k věrozvěstům blízký vztah; napsal kantátu Cyril a Metoděj, je autorem známé písně Ejhle, svatý Velehrad už zář́ (zpíváno též Ejhle, oltář Hospodinưv zárí) a zajištoval v roce 1869 hudební produkci v rámci oslav 1000. výročí úmrtí sv. Cyrila. Zde již čtrnáctiletý Janáček hořel pro slovanskou věc a bezmála ve vytržení očekával velehradské slavnosti, pro něž si na strýci Janu Janáčkovi (1810-1889) vymohl slovanský šat z „ruského plátna. “1 Bližší vztah k ruské kultuře a jazyku, který přerostl v nadšené rusofilství, můžeme sledovat od počátku sedmdesátých let. Mladý Leo (toto znění jména užíval do roku 1868) začal užívat podobu jména Lev, k tomu se patrně kolem roku 1873 přidal zájem o ruský jazyk a literaturu. V prvním roce svého sbormistrovského působení v Besedě brněnské v roce 1876 uvedl svůj melodram pro recitaci a orchestr na Lermontovu báseň Smrt. K tomu přichází přátelství s výrazně slovansky orientovaným Antonínem Dvořákem (1841-1904), stejně jako obdiv a touha po studiu u klavíristy Antona Rubinštejna (1829-1894). Obdivoval i tvorbu Čajkovského. Janáček demonstroval své rusofilství také volbou jmen svých dětí: Olga (1882-1903) a Vladimír (1888-1890). Janáčkův zájem o Rusko ještě posílil odchodem jeho bratra Františka (1856-1908) do Petrohradu, se kterým vedl korespondenci v ruštině a třikrát jej v Rusku navštívil. Byl také v úzkém spojení s ženským vzdělávacím spolkem Vesna, který především díky rusofilsky orientovanému řediteli Františku Marešovi (1862-1941) nakupoval ruskou literaturu, a od poloviny devadesátých let pak pořádal kurzy ruštiny, které vedl filolog a profesor I. české reálky PhDr. Ferdinand Jokl (1861-1905). Tato orientace Vesny, jež byla v nejužším spojení s brněnskou českou elitou, vedla v roce 1898 k založení Ruského kroužku. Mezi zakládajícími členy byl zmíněný František Mareš a Ferdinand Jokl, dále knihkupec Joža Barvič (1853-1924) či lékař MUDr. František Veselý (1862-1923), a pochopitelně nemohl chybět ani ředitel varhanické školy, Leoš Janáček. Ten byl po celou existence spolku v různých funkcích představenstva a v letech 1909 až 1915 dokonce jeho předsedou. Ruský kroužek deklaroval svou hlavní činnost jako výuku ruského jazyka s prostředky „cvičeni mluvnická, čteni deklamace, pěni, noviny, žurnály, bibliotheka, schůze členské, zábavné (čajové) večery, přednášky o mluvnici a literatuře ruské, vydávání přislušných tiskopisů a učebných pomůcek“2 a pochopitelně s nutným paragrafem „rozhovory o politice jsou vyloučeny. "3 Spolek byl velmi aktivní, a dokonce o jeho činnosti informovala

1 Dopis Leoše Janáčka z 26. 5. 1869, Janáčkův archiv Oddělení dějin hudby Uměnovědného muzea Moravského zemského muzea (dále JA MZM), sign. B 1731. Citováno z: Zahrádka, Jiří a kolektiv (ed.): Korespondence Leoše Janáčka [online]. Brno 2016 [cit. 5-9-2017] (dále KLJ)

2 Stanovy Ruského kroužku v Brně, Moravský zemský archiv (dále MZA), fond Policejní ředitelství v Brně B 26, sign. 648, kart. 2522B.

3 Ibid. 
pravidelně Moravská Orlice. Janáček byl v Ruském kroužku spokojený; dohlížel na výuku, zajištoval hosty pro přednášky, spoluorganizoval v roce 1899 oslavy k 100. výročí narození Alexandra Sergejeviče Puškina. Založená spolková knihovna postupně získávala úctyhodné množství literatury v ruštině. Ač činnost spolku byla velmi rozmanitá, hlavním cílem byla výuka jazyka. Velkou posilou byla rodilá Ruska Marie Nikolajeva Vevericová (1870-?), která vyučovala ruštinu, vedla konverzaci, deklamaci, čtení atd. Do kroužku docházela i Janáčkova chot Zdenka (1865-1938), dcera Olga a dokonce i služebná Marie Stejskalová (1873-1968). Zde Janáček poznával ruskou literaturu, která mu byla mentálně velmi blízká. Jistě ne náhodou vznikla většina děl inspirovaných ruskou literaturou právě v patnáctiletém období fungování spolku. Bylo to Klavírni trio na Tolstého Kreutzerovu sonátu (1908), později přepracované v Kvartet z podnětu L. N. Tolstého „Kreutzerovy sonáty “ (1923), Pohádka pro violoncello a klavír na Žukovského Pohádku o caru Berendéjovi (1910-13), rapsodie Taras Bulba na stejnojmennou Gogolovu novelu (1915, 1918). Výběr námětů vrcholných hudebně-dramatických díl jako opera Kát’a Kabanová (1920) na Ostrovského drama Bouře či opera Z mrtvého domu (1927-28) podle románu Fjodora Michailoviče Dostojevského Zápisky z Mrtvého domu jsou již spíše vedeny přímo zájmem o literární látku, nežli projevem rusofilství, které po válce u skladatele částečně odeznělo.

Vedle operních námětů je zřejmě nejvýznamnější realizací na ruskou literaturu právě Taras Bulba. Mimochodem to, že Janáček chápal hlavní postavu jako symbol ruské nezdolnosti, je běžný dobový jev, jelikož v naší společnosti do konce 1. světové války prakticky neexistovalo povědomí o svébytnosti ukrajinského národa. Janáček patrně poprvé přečetl Gogolovu historickou novelu v roce 1905, jak napovídá exemplář zachovaný v Janáčkově pozůstalosti. ${ }^{4}$ Jde o vydání v ruském jazyce vytištěné v Petrohradu roku 1901. Janáček si do tohoto exempláře zapsal poznámky k překladu, nápěvky a dvě data 6. a 13. března 1905. Taras Bulba se skutečně v té době v Ruském kroužku četl, jak dokládá ve své vzpomínce učitelka Vesny a členka kroužku, Antonie Pitourová (1872-1960): „A já mám ještě jeden pěkný soukromý zážitek z Kroužku. Četli jsme Tolstého, Gogola, Korolenka, Ševčenka a jiné. A jednou je na programu Taras Bulba. Tušim, že to bylo v roce 1905. Janáček předsedal uprostřed široké strany stolu. Měl sousedy po pravici i po levici. My s Olgou Vaškovou jsme sedávaly naproti němu. Četlo se mi jednou nĕjak lehce dobře. Možná, že mě učitel nechal déle čísti, nevím. Když řekl dosti, prestala jsem čisti, posunu knihu a pozvednu oči a vidím, že Janáček se na mne dívá a nevidi mne a cítim, že nevidi nikoho z nás. Je mi, jako by to byla nějaká svatá chvile a trnu, že učitel řekne dále a přeruši kouzlo Janáčkova vidění. Nevím, jestli si toho povšimnul, ale skutečně po malé prestávce řiká dále a Janáčův výraz obličeje se mění. Pravá ruka, kterou míval vždy ležeti na stole, zvedne tužku a tuká vedle knihy. Sklopím oči do knihy, abych četla sebou, ale cítim, jakoby něco zvláštniho, vzácného bylo kol osoby Janáckovy. "5

Příběh kozáckého atamana a jeho synů Janáčka nepochybně ihned zaujal. Taras měl dva syny, Andrije a Ostapa. Vkládal do nich naději, že z nich vyrostou stateční kozáci. Mladší Andrij se však za svého pobytu v Kyjevě zamiloval do krásné Polky a pro ni zradil za protipolského tažení své Záporožce. Za tento čin odsoudil Taras svého syna k smrti.

4 Kniha je uložena v JA MZM, sign. JK 46.

5 PITOUROVÁ, Antonie. Vzpomínky na Leoše Janáčka. Strojopisný text je uložen v JA MZM, sign. D 187 LJ. 
Smutný konec stihne i staršího ze sourozenců - Ostapa. Ten je zajat Poláky. Aby svého syna zachránil, pronikne Taras tajně až do Varšavy, ale už je pozdě. Když Ostapa popravují, alespoň se synovi ozve - je mu v těžké chvíli nablízku. Poté ve zmatku mizí v davu. Taras se Polákům za vše krutě pomstí, když se ale po boji vrací pro ztracenou dýmku, je zajat a okamžitě popraven upálením. V největších mukách hrdinně volá na prchající Záporožce, jak mají vyváznout z polského obležení.

Nežli však skladatel přistoupil ke kompozici podle příběhu „proroka slovanstva“6, uběhlo bezmála deset let. Proč se Janáček upjal k této látce, je pochopitelné. On, výsostný humanista, nadto rusofil, musel být otřesen válečným konfliktem, ve kterém byli nuceni Slované bojovat proti Slovanům. Již na samém počátku války, 2. srpna 1914, napsal své neteři Veřre Janáčkové (1891-1967): „Bude to hrozný boj germanstva proti slovanstvu. Tím hroznějš́, že my se diváme na vše jako vưl na porážku vola. "7 Byla to pro Janáčka doba skličující, vždyṫ do boje odcházelo i mnoho jeho žáků, z nichž se mnozí nevrátili.

\section{První verze slovanské rapsodie}

Tarase Bulbu, tehdy jako „slovanskou rapsodii“, začal Janáček komponovat 22. ledna 1915, jak dokládá jedno z dat na autografu ${ }^{8}$ první verze díla. První znění do Cody dokončil 18. června téhož roku, následně však do 2. července dopracoval ještě Codu. Totéž datum čteme i na dopise dirigentu a skladateli Otakaru Ostrčilovi (1879-1935), v němž jej žádá o pomoc: „Napsal jsem větš́ orchestrovou práci. Poprosím Vás potom, abyste mi to aspoň tak z listu prehráli - beze vši myšlenky na veřejné provedeni: abych jen na určito věděl, kde a jak polepšit. “9 Je jisté, že k takovému „zkouškovému“ provedení Ostrčilem s jeho Orchestrálním sdružením nedošlo. To nastudovalo až v roce 1917 premiéru skladby Šumařovo dítě. Opis autografní verze Tarase Bulby zadal Janáček kopistovi Vojtěchu Ševčíkovi (1881-1955), v té době hornistovi Vinohradského divadla, jak naznačuje Ševčíkův dopis z 27. ř́́jna $1915,{ }^{10}$ ve kterém Janáčka ubezpečuje, že opis nejmenované skladby snad do Vánoc dokončí. ${ }^{11}$

Pak ale Janáček práci na své rapsodii na více než dva roky odložil, neusiloval dále o „vyzkoušení“ partitury ani o veřejné provedení. Důvodů mohla být celá řada. Měl jistě spoustu jiné kompoziční práce: v roce 1915 napsal Houslovou sonátu, počátkem roku 1916 pak všechny své ženské sbory, cyklus Hraď̌anské pisnicky, Kašpara Ruckého i Vlčí stopu. Také chtěl co nejdříve dokončit letitou práci na opeře Výlet pana Broučka do Měsice, tím spiše, že se mu po úspěšné pražské premiéře Jeji pastorkyně nabízela možnost uvést ji

6 Janáček tak nazval Tarase Bulbu v dopise Kamile Stösslové z 3. 6. 1927. Dopis je uložen v JA MZM, sign. E 441. Citováno z KLJ.

7 Dopis Leoše Janáčka Věře Janáčkové je uložen v JA MZM, sign. B 2322. Citováno z KLJ.

8 Autograf je uložen v JA MZM, sign. A 23.505.

9 Dopis Leoše Janáčka Otakaru Ostrčilovi je uložen v JA MZM, sign. B 2106. Citováno z KLJ.

10 Dopis Vojtěcha Ševčíka Leoši Janáčkovi z 27. 10. 1915 je uložen v JA MZM, sign. A 2575. Citováno z KLJ.

11 Opis této verze je uložen v JA MZM sign. A 33.789 a. 
poprvé na prknech Národního divadla. Následně pak během roku 1917 zkomponoval Výlet pana Broučka do XV. století. Pravý důvod přerušení práce byl ale nejspís jiný. V roce 1915 panovala ve válkou zmítané habsburské monarchii velmi napjatá politická a společenská situace. Již v březnu toho roku, tedy v plné práci na Tarasu Bulbovi, pocítil Janáček tlak brněnského c. k. Policejního ředitelství plynoucí z jeho rusofilských aktivit. Úřady se nedlouho po vypuknutí válečného konfliktu a po vyhlášení války Rusku 1. srpna 1914 pochopitelně zaměřily na velmi aktivní brněnský Ruský kroužek. A tak Janáček, jako předseda spolku, obdržel 9. března 1915 oznámení, v němž jej policejní ředitelství na základě výnosu c. k. Moravského místodržitelství ze dne 27. února 1915 informovalo o rozpuštění Ruského kroužku. Jako důvody takového opatření byly uvedeny snahy kroužku o kontakty s ostatními rusofilskými kruhy, přijímání časopisů a knih z Petrohradu, přednášky a koncerty nevhodných osob (např. dirigenta a člena ruského vyslanectví ve Vídni Anatolie Archandělského) a také uvedení „ódy na v̌šmohoucnost Ruska“, tj. Puškinovy básně Ruským pomlouvačům na slavnostech k 100. výročí básníkova narození v roce 1899. Závěrem dopisu se píše: „ [...] muss die Tatsache, dass der Verein mit russischen Kreisen in Fühlung steht und Sympathien für ein Reich pflecht, das sicht mich der Monarche Kriegszustande befindet, als im hohen Grade staatsgefährlich bezeichnet werden."12 Poté, 27. března 1915, policie provedla za přítomnosti Janáčka a jednatelky Olgy Vaškové (1873-1944) domovní prohlídku se zajištěním spolkového majetku. ${ }^{13}$ Není divu, že mnohé materiály nařídil Janáček už předtím okamžitě spálit. ${ }^{14}$ Nastalo dlouhé dohadování o likvidaci spolkového majetku a především předání knihovny o 277 svazcích spolku Brněnská Matice školská. Celé jednání skončilo až 22. ledna 1916 soudním rozhodnutím o nemožnosti předání zabavené knihovny Brněnské Matici školské. ${ }^{15}$ Janáček byl navíc jistě dobře informován od Olgy Vaškové, sestry Petra Bezruče, o básníkově zatčení a obvinění z velezrady pro údajné autorství oslavné básně na ruská vojska a cara Mikuláše II, uveřejněné v pařižském krajanském odbojovém časopisu L'Independance tchèque. Není divu, že v tomto ovzduší strachu Janáček na své rusofilství nemínil dále upozorňovat. To také dokládá Janáčkova odpověd' na otázky redaktora Hudební matice Umělecké besedy Otakara Nebušky (1875-1952) z 24. listopadu 1916 vztahující se k opeře Výlet pana Broučka do Měsice: „Vím jen, že po Broučkovi psal jsem ještě Šumařovo ditě, ženské sbory a symfonickou druhou básě̌ jejiž jméno zamlčuji. "16 Jak vlastně tato první verze vypadala, můžeme doložit z kompletně dochovaného autografu. Celá skladba s vloženými třemi Recitativy byla rozsáhlejší než dnešní znění. Především se to týká první věty, která začínala dlouhým oddílem, později zrušeným. Podobně vypadl i rozměrný úsek po dnešní druhé větě. I zbývající části se však v mnohém liší a to nejenom v samotném hudebním materiálu, ale také instrumentací. Tak např. v Codě nebyly použity varhany, které byly předepsány v první větě a to v daleko

12 Dopis brněnského Policejního ředitelství Ruskému kroužku ze dne 27. února 1925 je uložen v MZA, fond Policejní ředitelství v Brně B 26, sign. 648, kart. 2522B.

13 Protokol je uložen v MZA, fond Policejní ředitelství v Brně B 26, sign. 648, kart. 2522B.

14 VRBA, Přemysl. Ruský kroužek v Brně a Leoš Janáček. In Slezský sbornik, roč. 58 (1960), č. 1, s. 71.

15 Soudní rozhodnutí c. k. okresního soudu Brno město z 22. 1. 1916 je uložené v MZA, fond Policejní ředitelství v Brně B 26, sign. 648, kart. 2522B.

16 Kopie dopisu Leoše Janáčka Otakaru Nebuškovi je uložena v JA MZM, sign. D 557. Citováno z KLJ. 
exponovanější podobě, než je známe dnes. A v instrumentaci také nenalezneme např̀. anglický roh. K této verzi opsané Vojtěchem Ševčíkem se Janáček vrátil až v roce 1918, kdy vize konce války a politických změn dávala takové činnosti smysl.

\section{Druhá verze slovanské rapsodie}

O revizi skladby informuje Janáček v dopise z 25. března 1918 svou přítelkyni, pražskou Kostelničku, Gabrielu Horvátovou (1877-1967): „Našel jsem si už práci: děj světový už se tak vyviji, tak hrozně, že možno jen do černé budoucnosti volat ... Vzal jsem do ruky svou závět hudebni, slovanskou rhapsodii pro orchestr. Dokončím čistku jeji ted’ o prázdninách velkonočních. "17 Svou intenzivní práci na Tarasovi Bulbovi Horvátové potvrzuje o čtyři dny později, 29. března: „Já dal jsem do čistoty velkou orchestrálni rhapsodii. Na vzkřrišseni budu zcela s ni hotov. Pracoval jsem usilovně tyto dny. " 18 V revidovaném Ševčíkově opisu partitury čteme na poslední stránce Janáčkem zapsaný údaj: Od r. 1915 - Velký pátek r. $1918 .{ }^{19}$ Velký pátek roku 1918 pak připadá právě na 29. březen, takže skladatel nakonec ukončil revizi dříve. Skladba doznala zásadních změn a to především ve škrtech v první a poslední části. Výrazněji upravené stránky z původního opisu ${ }^{20}$ nechal Janáček následně přepsat kopistu Václava Sedláčka (1879-1944), flétnistu brněnského Národního divadla. Tyto nové stránky tvoří cca $1 / 3$ původního opisu, skladatel však zasahoval i do stávajících stránek. ${ }^{21} \mathrm{~V}$ tomto znění již nacházíme anglický roh či varhany v Codě. Po opisu partitury se Sedláček pustil do rozepisování orchestrálních hlasů;22 jeho vyúčtování nese datum 9. listopadu 1918. ${ }^{23}$ Partitura nadepsaná jako Taras Buljba, Slovanská rapsodie nenese v této fázi názvy jednotlivých vět (Taras Buljba je možnou variantou přepisu). Dílo tak bylo, vzhledem k okolnostem konce války a vzniku Československa, připraveno k provedení právě včas. Došlo k němu však až v roce 1921.

\section{První uvedení rapsodie}

Během pravidelného letního pobytu v Luhačovicích v roce 1921 Janáčka písemně kontaktovali dva dirigenti, kteří o dosud neprovedené dílo projevili zájem. Nejprve to byl Václav Talich (1883-1961), dirigent České filharmonie, který Janáčka vyzval dopisem

17 Dopis Leoše Janáčka Gabriele Horvátové je uložen v JA MZM, sign. B 2569. Citováno z KLJ.

18 Dopis Leoše Janáčka Gabriele Horvátové je uložen v JA MZM, sign B2571. Citováno z KLJ.

19 Opis partitury je uložen v JA MZM, sign. A 49.313.

20 Nepoužité části původního Ševčíkova opisu s Janáčkovými úpravami jsou uloženy v JA MZM, sign. A 33.789 .

21 Viz pozn. 19.

22 Orchestrální hlasy se nedochovaly.

23 Dopis s účtem je uložen v JA MZM, sign. D 171. Citováno z KLJ. 
z 1. srpna, aby mu dal k dispozici některou dosud neprovedenou orchestrální práci pro Jubilejní sezónu České filharmonie. ${ }^{24}$ Janáček mu ihned nabídl svého Tarase Bulbu: „Mám rhapsodii Taras Buljba pro orchestr. Hlasy jsou rozepsány; třeba v nich jen málo oprav. "25 Talich byl zprávou potěšen a odpověděl, že by rád zařadil dílo hned do prvního abonentního koncertu. ${ }^{26}$ Dva dny po Talichově žádosti se o provedení ucházel také František Neumann (1874-1929), šéf opery brněnského Národního divadla: „Rád bych provedl v Praze se Šakovou Filharmonii Vaše symphonické básně: ,Ballada blanická‘ a ,Taras Bulba‘ Račte mi laskavě sděliti, zdali s tím souhlasíte, a zda materiál obou skladeb mi $k$ tomu účelu zapưjčite. Bylo by mi velmi milé, kdybyste pred těmito koncerty nikomu v Praze nedal povoleni k provedeni těchto Vašich skladeb. "27 Janáček byl zájmem těchto vynikajících dirigentů jistě potěšen, ale zároveň se dostal do svízelné situace, kdy se musel rozhodnout, komu má premiéru díla přenechat. Neumannovi tedy odpověděl, že sice rád svěřuje svá díla právě jemu, ale že Tarase Bulbu již přislíbil Talichovi. ${ }^{28}$ Po osobním rozhovoru s Neumannem se ale nakonec rozhodl pro něj. Byla to racionální úvaha. Janáček měl k Neumannovi naprostou důvěru, vždyt' jej sám v roce 1919 prosadil na místo šéfa brněnské opery. Věděl, že nastudování bude na vynikající úrovni a také mohl během zkoušek korigovat partituru s dirigentem, se kterým již měl velké zkušenosti. Zároveň však nechtěl zklamat Talicha, který dosud žádnou jeho skladbu nedirigoval, proto mu v dopise z 25. srpna celou situaci citlivě vysvětlil: „Jistě bych byl rád slyšel svou práci pod Vaši taktovkou. Je zapotřebi těch výhrad prvenstvi? Chef Neuman [!] chce totéž dávati i v Brně i v Praze. Jest přirozené, že když .mohu býti $v$ Brně př́tomen zkouškám a ledacos když mohu hned opravit - než to dojde do Prahy, že jsem mu ted' notový materiál dal. Možná, až to uslyšite, že si řeknete: ,dobře že jsem do toho nelezl. ' . $N u$, a když by to stálo $i$ za druhé provedeni?"29 Premiéra díla se nakonec konala v Brně a to s užitím partitury prvního opisu verze 1918 (Ševčík - Sedláček). Taras Bulba pod názvem „Taras Buljba“ Rapsodie dle Gogola pro orchestr zazněl na I. symfonickém koncertě orchestru Národního divadla v Brně 9. ř́jjna 1921. Dále zazněla Symfonie č. 2 Jaroslava Kvapila (1892-1958), Dvořákova předehra $V$ př́rodě a Smetanova symfonická báseň $Z$ českých luhů a hájů. Zde již nefiguroval podtitul Slovanská rapsodie, název byl nahrazen zkrácenou variantou. Janáček byl s provedením své skladby velmi spokojen, jak vysvítá z dopisu dirigentovi večera Františku Neumannovi: „Bud'te tak dobrý a vyslovte všemu orchestru Národniho divadla můj srdečný dik za provedeni mého díla, Tarase Buljby. Dostalo se mi od tak mnohých pánů - i pi. Škvorové - tolik pochvalných slov, kterých si vážim a za které zvláště děkuji. Vám pak, milý šefe, že Jste vybral mé dílo v programy koncerti̊, zvláště děkuji. Bylo by leželo v truhle - a myslím ted, že škoda by toho bývalo. “30 $\mathrm{O}$ dva dny později dodává: „Velevážený přiteli!

24 Dopis je uložen v JA MZM, sign. D 359. Citováno z KLJ.

25 Nedatovaná pohlednice je uložena v Muzeu českého krasu v Berouně, sign. T 757. Citováno z KLJ.

26 Korespondenční lístek Václava Talicha Leoši Janáčkovi je uložen v JA MZM, sign. A 966. Citováno z KLJ.

27 Dopis Františka Neumanna Leoši Janáčkovi z 3. 8. 1921 je uložen v JA MZM, sign. D 339. Citováno z KLJ.

28 Pohlednice Leoše Janáčka Františku Neumannovi ze 4. 8. 1921 je uložena v JA MZM, sign. A 6091. Citováno z KLJ.

29 Dopis je uložen v Muzeu českého krasu v Berouně, sign. T 1226. Citováno z KLJ.

30 Dopis Leoše Janáčka Františku Neumannovi z 10. 10. 1921 je uložen v JA MZM, sign. B 1003. Citováno z KLJ. 
K svému prvému dopisu připojuji: Komu čest, tomu čest! Svou skladbu nejlépe asi znám. Dirigováním vystižena byla ideově a vyhrána byla virtuosně. Kéž by se to tak podařilo i v Praze!"31 V Praze se Šakovou filharmonií byl koncert plánován na 6. listopadu $1921^{32}$, ale s největší pravděpodobností se nakonec nekonal. Kritik na premiéru Janáčkovy novinky vyšlo poskrovnu a jsou spíše rozpačité: „O jejich hudebnich vlastnostech nebude jako o ostatnich pracích Janáckových svorného soudu. Formalista pohorši se podivinskými harmonickými útvary pohoršil by se snad ještě vice, kdyby je vidèl napsány - úsečnými aforismy, setrvačně opakovanými nebo stř́danými bez organické stavby, nahromaděnými obtí̌emi instrumentálními, jejichž smyslu $v$ prvé chvili těžce postřehnout. “33 V závěru však připouští velkou působivost díla, která dle recenzenta příliš nevyzněla, pro ne zcela precizní nastudování tak náročné skladby. K tomuto provedení také musel Václav Sedláček rozepsat více smyčcových partů, jelikož v roce 1918 byly party pro smyčce pořízeny většinou pouze v jednom exempláři. Účet však z velké části uhradilo brněnské divadlo. ${ }^{34}$ Po premiérovém koncertu pak partituru ještě jednou opsal Vojtěch Ševčík, v té době již hornista brněnského divadla. Tento opis již nese pouze podtitul „rapsodie“ a obsahuje změny a doplňky, které vznikly během prvního Neumannova nastudování týkající se především detailně vypracované dynamiky. ${ }^{35}$

Bezmála po roce od Talichovy žádosti mu Janáček zaslal 1. července 1922 partituru Tarase Bulby, ${ }^{36}$ zřejmě nově pořízený Ševčíkův opis. Avšak Talich se dopisem z 6. září 1922 omluvil: „[...] nedivte se ani se nehoršete, že neuvidíte na letošním generálním pořadu,Tarase Bulbu: Dưvody více méně praktického rázu vedly mě k tomu, že zamýšlený letos cyklus české básně symfonické, jsem rozdělil do dvou saison. Letos budou provedeny básně jednodílné (mezi nimi

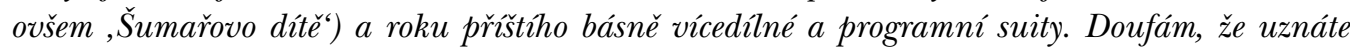
principielnost di̊vodu, jež vedla ke změně a zachováte mně i nadále své vzácné prátelstvi. "37

\section{Další nastudování}

Podruhé byl Taras Bulba opět proveden Františkem Neumannem v Brně, a to 21. ledna 1924 na slavnostním koncertě u příležitosti Janáčkova a Sukova životního jubilea. Stočlenný orchestr tvořený souborem Národního divadla a rozšířený o žáky konzervatoře a hráče Německého divadla přednesl vedle Janáčkovy rapsodie ještě Sukovo Zráni. Zde byly

31 Dopis Leoše Janáčka Františku Neumannovi z 12. 10. 1921 je uložen v JA MZM, sign. B 2173. Citováno z KLJ.

32 Dopis Leoš Janáček Václavu Talichovi z 28. 10. 1921 je uložen v Muzeu českého krasu v Berouně, sign. T 758, též dopis Leoše Janáčka Kamile Stösslové z 23. 10. 1921 je uložen v JA MZM, sign. E 1143. Citováno z KLJ.

33 ČERNUŠÁK, Gracian (šifra -k). Z brněnských koncertů. In Lidové noviny, roč. XXIX (1921), č. 509 (11. 10.), s. 7.

34 Dopis Václava Štecha Leoši Janáčkovi z 15. 10. 1921 je uložen v JA MZM, sign. D 342. Citováno z KLJ.

35 Opis partitury je uložen v JA MZM, sign. A 39.739.

36 Dopis Leoše Janáčka Václavu Talichovi z 1. 7. 1922 je uložen v Muzeu českého krasu v Berouně, sign. T 759. Citováno z KLJ.

37 Dopis Václava Talicha Leoši Janáčkovi z 6. 9. 1922 je uložen v JA MZM, sign. D 404. Citováno z KLJ. 
jednotlivé věty v programu označeny: a) Řež u Dubna, b) Varšavské trýzně a c) Upálení. Dílo bylo nastudováno, stejně jako v roce 1921, z opisu partitury Ševčík - Sedláček z roku 1918. Mimochodem skladatel na koncertě nebyl přítomen, jelikož divadlo mu zapomnělo předat pozvánku a vstupenky. ${ }^{38}$

Janáček se pražského provedení dočkal až v listopadu 1924. Václav Talich 24. června 1924 opětovně požádal Janáčka o možnost uvedení díla ${ }^{39}$ a ten nadšeně souhlasil. ${ }^{40}$ Břetislav Bakala (1897-1958), který připravoval čtyřruční klavírní úpravu rapsodie z Ševčíkova opisu z roku 1921 (viz níže), ji v srpnu doručil Talichovi a v zář́i byly do České filharmonie zaslány i party. ${ }^{41}$

Před pražským provedením byl Janáček vyzván, aby napsal krátký popis skladby do programu koncertu. Janáček napsal:

\section{"Taras Bulba (1628)}

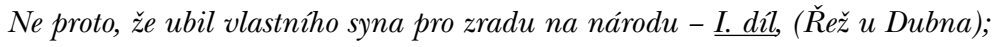

ne pro mučenickou [!] smrt druhého syna - II. díl, (Varšavské trýzně);

ale, že „nenajdou se na svètě ty ohně, muka, jež by zničila sílu ruského lidu“ - pro tato

slova, jež padaji do palčivých jisker a plamenů hranice, na niž dotrpèl slavný hejtman kozácký Taras

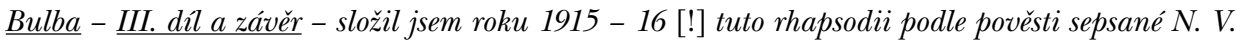

Gogolem. "42

Datum koncertu České filharmonie bylo stanoveno na 9. listopad 1924. Janáček byl vyzván, aby se zúčastnil generální zkoušky 7 . listopadu ${ }^{43}$ a svou účast také potvrdil Václavu Talichovi: „Vim, že to provedete dobře, ale přece dojedu ku generálni zkoušce. Když by něco bylo, dovolite mi poopravit? " 44 Přestože měl Janáček večer před touto zkouškou v Brně premiéru opery Příhody lišky Bystroušky s následnou slavnostní večeří v hostinci U Polenků, svůj slib dodržel a v noci odjel vlakem do Prahy, aby byl v 9. hodin v Smetanově síni přítomen. Václav Talich na Janáčkovu účast vzpomíná: „Mám moji proni zkoušku na ,Tarase Buljbu: Neskončil jsem dosud své př́pravné studium a při přehráváni posledni věty narazim před vrcholem na misto ,dopio movimento', zdvojim tedy mechanicky tempo, z pưli se stanou čtvrtky, ale hráči pruých $i$ druhých housli vali hrůzou oči nad závratnou rychlosti arpeggiovitého pohybu jim přidaného a obávám se poněkud sám, bude-li to dlouho trvati, že to snad skonči vyvrtnutím ramenniho kloubu u některého hráče. Konečně jsme dorazili štastně na druhý břeh a závěr skladby jsem tentokráte pojal výjimečně jako chvalozpěv za štastně skončenou plavbu. Téhož dne

38 O tom více: ZAHRÁDKA, Jiří. „Divadlo nesmi býti lidu komedii“. Leoš Janáček a Národni divadlo v Brně. Moravské zemské muzeum, Brno 2012, s. 99-100.

39 Dopis Václava Talicha Leoši Janáčkovi z 24. 6. 1924 je uložen v JA MZM, sign. D 447. Citováno z KLJ.

40 Dopis Leoše Janáčka Václavu Talichovi z 1. 7. 1924 je uložen v Muzeu českého krasu v Berouně, sign. T 761. Citováno z KLJ.

41 Dopis České filharmonie Leoši Janáčkovi ze 4. 9. 1924 je uložen v JA MZM, sign. A 3630.

42 Dopis Leoše Janáčka Richardu Veselému je uložen v JA MZM, sign. B 1746. Citováno z KLJ.

43 Telegraf České filharmonie Leoši Janáčkovi je uložen v JA MZM, sign. A 4572. Citováno z KLJ.

44 Korespondenční lístek Leoše Janáčka Václavu Talichovi ze 4. 11. 1924 je uložen v Muzeu českého krasu v Berouně, sign. T 763. Citováno z KLJ. 
odpoledne jsem měl vyučováni na konservatoři a sotva, sotva jsem se mohl dočkat okamžiku, kdy osamotím ve své učebně, abych zamíril oko i ucho na sporné místo. Netrvalo nijak dlouho a př́čina byla odhalena. Janáček neměni rád visuelni formu své tematiky. Nechal houslisty, hrajicí před ,doppio movimento“ šestnáctiny pokračovati v témže pohybu i po tom novém prepisu, takže z predepsaných šestnáctin se staly nehratelné dvaatřicetiny. Šṫasten z objevu vstupuji nazitř́ do předpokoje Smetanovy sině. To překvapení! Janáček, který měl minulého večera nějakou svoji premiéru v Brně, sedi tu vzpřimeně se svoji vzdorovitou palici a vítá mě velikým pohledem. Ani stopy po probdélé noci. Hovořime o to $i$ onom a netrpělivě čekám na okamžik, kdy budu moci prevésti hovor na sporné misto v ,Tarasu Buljbovi`. Otázku stylizuji diplomaticky: ,v mistě, kde přecházíte v zkrácený pohyb, má přece býti v houslich průběžný pohyb šestnáctin, že ano? ,Pravda odpovídá mistr. ,Pak je ovšem třeba, aby od taktu označeného ,doppio movimento' hráli houslisté o polovinu méně not t. j. misto šestnáctin osminy. ', Vidite, vidite', vybuchne Janáček, ,já to tušil, $\check{z}$ je je tam někde rytmická chyba, a když jsme to dávali s Neumanem [!] v Brně, nepř̌̌sli jsme na to. ' Chyba byla tedy štastně opravena, a poněvadž se tak stalo za Janáčkova života, vyvázl jsem ze situace se zdravou kůží. Stát se to po smrti, dopustil bych se podle názorů některých našich sv. Aloisů falšování zápisu a byl bych právem útrpným souzen. ${ }^{45}$ Janáček se však nespokojil s touto improvisovanou korrekturou, poněvadž změnou šestnáctin v osminy, byt' auditivně se téma nezměněno, byla porušena jiná zvláštnost janáčkovského zápisu, jež se jevi ve visuálni ostinátnosti jeho tématiky. V pozdějš́ tištěné partituře je úsek, o němž tu hovořím, překomponován, ,doppio movimento" zmizelo a houslisté si hraji svoje šestnáctiny, které zůstávaji šestnáctinami po celou dobu i pro oči. " ${ }^{46}$ Skutečně v Ševčíkově opisu partitury je toto řešení v Codě (takt 91-118) Talichem zaznamenáno.

V Praze tak zazněl poprvé Taras Bulba 9. listopadu 1924 v Smetanově síni Obecního domu, tentokrát pod názvem Taras Buljba, rhapsodie bez popisu a názvu jednotlivých vět. Janáček byl s provedením velmi spokojený, jak dokládá dopis zaslaný bezprostředně po koncertu: „Vzorným nastudováním Tarase Bulby udělal jste mi velkou radost. [...] Děkuji ještě všem pánům v orchestru a Vám obzvláště. Poznal jsem Vaši výtečnou metodu v studováni; Vaše jisté postřehy nedostatků, milé, klidné a věcné opravy a jistotu, s jakou vyšinujete dílo na to sluničko, kde se zaleskne. “47 Talich provedl Tarase Bulbu (poprvé pod tímto názvem) ještě krátce nato, 8. prosince 1924, na koncertě věnovaném skladatelovým sedmdesátým narozeninám, kde byl př́itomen nejenom Janáček, ale i prezident republiky T. G. Masaryk. Za svou rapsodii získal v tomto roce státní cenu a s ní spojený obnos 5000 Kč. ${ }^{48}$

45 Narážka na článek Vladimíra Helferta Závaznost dokumentu (Index, roč. IX-1937, č. 6, s. 64-66), který publikoval proti Talichově úpravě instrumentace Janáčkovy opery Př́hody lišky Bystroušky při nastudování opery v pražském Národním divadle v roce 1937.

46 Sešit se zápisky je uložen v Muzeu českého krasu v Berouně, sign. T 3681. Citováno z KLJ.

47 Dopis Leoše Janáčka Václavu Talichovi je uložen v Muzeu českého krasu v Berouně, sign. T 767. Citováno z KLJ.

48 Dopis Ministerstva školství a národní osvěty Leoši Janáčkovi z 24. 10. 1924 je uložen v JA MZM, sign. C 93. Citováno z KLJ. 


\section{Nakladatelé - tištěné vydání úpravy pro klavír a finální verze partitury}

Jako prvního nakladatele po vydání Tarase Bulby Janáček oslovil 21. září 1922 svého nakladatele Universal Edition. ${ }^{49}$ Učinil tak v mezidobí, kdy mu Talich partituru vrátil s tím, že dílo provede až v sezóně 1923/24. Nakladatelství jej sice požádalo o zaslání partitury, ${ }^{50}$ téma skladby však bylo pro poválečné poměry v Rakousku a na německém trhu poněkud problematické, jak vysvítá z dopisu ředitele Universal Edition Emila Hertzky (1869-1932) z 25. 11. 1922: „Was Taras Bulba betrifft, so ist das ein wunderschönes Orchesterwerk, das ich, wenn wir nicht jetzt so masslos überbürdet wären, [!] bestimmt machen würde. Aber die Verhältnisse sind in Deutschland und Oesterreich jetzt so ausserordentlich schwierige, dass ich mich nicht getraue, das Werk zu vervielfältigen. "51

Poté, co partituru odmítla vydat Universal Edition, projevila o dílo zájem pražská Hudební matice Umělecké besedy. Ta se na své schůzi 21. prosince 1923 rozhodla, že partituru vydá s podmínkou, že skladba bude provedena na pražském mezinárodním festivalu soudobé hudby (ISCM) plánovaném na přelom května a června $1924 .{ }^{52} \mathrm{Na}$ pořad žádného ze tří orchestrálních koncertů se však Taras Bulba nakonec nedostal. V lednu 1924 přijel do Brna zástupce Hudební matice Otakar Nebuška. Vedle účasti na generální zkoušce slavnostního koncertu k Janáčkovým sedmdesátinám ${ }^{53}$ měl především $\mathrm{s}$ Mistrem dohodnout vydání úpravy Tarase Bulby pro čtyřruční klavír, který by vypracoval Janáčkův žák Břetislav Bakala ${ }^{54}$. V srpnu odevzdal Bakala hotovou klavírní úpravu skladby. ${ }^{55}$ Ještě před pražskou premiérou Tarase Bulby však vyšlo najevo, že Bakalova transkripce neodpovídá zcela partituře ${ }^{56}$ Není divu, že v nakladatelství měli o Bakalově úpravě pochyby, protože jim byl patrně k dispozici pouze opis Ševčík - Sedláček z roku 1918, který byl poněkud nepřehledný, a navíc s ním Bakala nepracoval - ten při úpravě vycházel z pozdějšího Ševčíkova opisu z roku 1921. Sjednocení úpravy s opisem Ševčík - Sedláček se ujal skladatel Ladislav Vycpálek (1882-1969) a korektor Průmyslové tiskárny Jindřich

49 Kopie dopisu Leoše Janáčka Universal Edition z 23. 9. 1922 je uložena v JA MZM, sign. B 1976. Citováno z KLJ.

50 Dopis Emila Hertzky Leoši Janáčkovi z 2. 10. 1922 je uložen v JA MZM, sign. D 987. Citováno z KLJ.

51 Dopis Emila Hertzky Leoši Janáčkovi z 25. 11. 1922 je uložen v JA MZM, sign. D 998. Citováno z KLJ.

52 Zápis ze schůze Vydavatelské komise Hudební matice Umělecké besedy z 21. 12. 1923 je uložen v Literárním archivu Památníku národního písemnictví (dále LA PNP), fond Umělecká beseda, kart. B 31 . O tom: LÁNA, Oldřich. Leoš Janáček a Umělecká beseda (1920-1928). Druhá fáze spolupráce. Disertační práce, Ústav hudební vědy, Filozofická fakulta, Masarykova univerzita, Brno 2017, s. 88.

53 Zápis ze schůze Vydavatelské komise Hudební matice Umělecké besedy z 11. 1. 1924 je uložen LA PNP, fond Umělecká beseda, kart. B 31. O tom: LÁNA, Oldřich. Leoš Janáček a Umělecká beseda (1920-1928). Druhá fáze spolupráce. Disertační práce, Ústav hudební vědy, Filozofická fakulta, Masarykova univerzita, Brno 2017, s. 89.

54 Ibid.

55 Dopis Hudební Matice Leoši Janáčkovi z 19. 8. 1924 je uložen v JA MZM, sign. D 1198. Citováno z KLJ.

56 Zápis ze schůze Vydavatelské komise Hudební matice Umělecké besedy ze 7. 11. 1924 je uložen LA PNP, fond Umělecká beseda, kart. B 31. O tom: LÁNA, Oldřich. Leoš Janáček a Umělecká beseda (1920-1928). Druhá fáze spolupráce. Disertační práce, Ústav hudební vědy, Filozofická fakulta, Masarykova univerzita, Brno 2017, s. 89. 
Máslo (1875-1964). Ale krátce po oznámení, že koncem února vyjde klavírní verze tiskem, se objevil další problém, jak ukazuje dopis Hudební matice z 23. února 1925: „Ve suém posledním dopise sdělil jsem Vám, že ,Taras Bulba“ vyjde do konce února. A tento klavirni výtah, mistře, měl čtyři korektury a to ještě po pražském provedeni našly se v klavírni úpravě Bakalově takové úchylky od partitury, že bylo nutno podrobiti ji znovu důkladné revisi a některé již vyryté plotny musily se prèrýti. Korektor tiskárny pan Máslo měl s drem Vycpálkem i s Talichem několik schuizek nad korekturami, které se vždy přehrávaly a přehližely. "57 I tato revize byla zřejmě provedena opět s opisem Ševčík-Sedláček z roku 1918, jelikož problematické místo v Codě (t. 97-118) neodpovídá Talichově úpravě provedené v Ševčíkově opisu z roku 1921. Bakalova úprava tak vyšla o měsíc později a pro nás je důležitou informací, spolu s Ševčíkovým opisem z roku 1921, jakou podobu mělo dílo před a po Talichově pražském nastudování. Janáček však toužil také po vydání partitury. Hudební matice sice Janáčkův provozovací materiál rapsodie nabízela k zapůjčení, ale vlastní si zatím nepořídila. Jelikož rukopisný materiál z roku 1917 a 1921 procházel četnými změnami a doplňky, tvořil s oběma opisy partitur poměrně nepřehledný celek. To se projevilo na plánovaném prvním provedení skladby v Londýně, které se mělo uskutečnit v říjnu 1926, tedy krátce po Janáčkově anglickém turné. K nastudování však nedošlo a důvod sdělil tehdejší velvyslanec v Londýně Jan Masaryk (1886-1948) v dopise Ministerstvu zahraničních věcí ČSR 22. listopadu 1926: „Nedávno známý anglický dirigent, Sir Henry Wood, získán byl pro provedeni Janáčkova díla ,Taras Bulba; avšak musel od svého záměru upustit, ježto neni tištěné partitury této skladby a zaslaný rukopis nevyhovoval. "58 Obdobná situace nastala o dva měsíce později, kdy o provozovací materiál požádal dirigent Walther Straram (1876-1933) pro provedení rapsodie v Pař́ži, plánované na březen roku 1927. Nakladatelství doporučilo posunutí termínu koncertu s odůvodněním, že Janáček si vzal materiál k sobě, aby provedl revizi díla. ${ }^{59}$ Taktéž nebyl vyřízen požadavek Záhřebské filharmonie. ${ }^{60}$ Mezitím, poté co byl provozovací materiál vrácen z Londýna, zazněl 5. prosince 1926 Taras Bulba na abonentním koncertě České filharmonie s dirigentem Františkem Stupkou (1879-1965) a ačkoliv orchestr hrál z tohoto materiálu již potřetí, měl s jeho srozumitelností velké problémy. Janáček opětovně žádal Hudební matici o tištěné vydání partitury a nový rozpis hlasů, ${ }^{61}$ ale nakladatelství z finančních důvodů této žádosti nevyhovělo. Naopak doporučilo skladateli pořídit nový opis provozovacího materiálu na vlastní náklady. ${ }^{62}$ Následně byla partitura vrácena Janáčkovi. Nakladatelství jej opět kontaktovalo 22. března 1927 s dotazem, jak je daleko s revizí a pořízením nového provozovacího

57 Dopis Hudební matice Leoši Janáčkovi z 23. 2. 1925 je uložen v JA MZM, sign. D 1199. Citováno z KLJ.

58 Dopis Jana Masaryka Ministerstvu zahraničí z 22. 11. 1926 je uložen v LA PNP, fond Umělecká beseda, celek 229. O tom: LÁNA, Oldřich. Leoš Janáček a Umělecká beseda (1920-1928). Druhá fáze spolupráce. Disertační práce, Ústav hudební vědy, Filozofická fakulta, Masarykova univerzita, Brno 2017, s. 90.

59 Dopis Hudební matice Leoši Janáčkovi z 19. 1. 1927 je uložen v JA MZM, sign. D 534. Citováno z KLJ.

60 Dopis Záhřebské filharmonie Leoši Janáčkovi z 18. 2. 1927 je uložen v JA MZM, sign. C100. Citováno z KLJ.

61 Dopis Hudební matice Leoši Janáčkovi z 24. 1. 1927 je uložen v JA MZM, sign. D 533. Citováno z KLJ.

62 Dopis Hudební matice Leoši Janáčkovi z 3. 2. 1927 je uložen v JA MZM, sign. D 540. Citováno z KLJ. 
materiálu, jelikož o skladbu znovu požádal dirigent Straram. ${ }^{63}$ To Janáčka rozlítilo a rázně Hudební matici odpověděl: „Co se týká p. Straramav Pařiži, račte mu sděliti: ,My, Hudebni Matice, nechali jsme tři léta ležet Taras Bulbu; vydali jsme zbytečný klavirni výtah - z něhož přece nelze orchestru hrát - a partituru jsme nevydali. Proto skladatel zamknul do truhly dilo to a nikomu ho více nevydá. “"64 Patrně tato výhrůžka vedla k rozhodnutí nakladatelství urychleně podat žádost o finanční podporu Českou akademii věd a umění a rapsodii co nejdříve vydat tiskem. ${ }^{65}$ Díky kladnému vyřízení žádosti nestálo již vydání partitury nic v cestě. Janáček provedl důkladnou revizi do partitury Ševčík-Sedláček z roku 1918, která v mnohém změnila podobu díla. Najdeme zde četné instrumentační doplňky ve všech částech, včetně vrcholu Cody. A jelikož patrně neměl po ruce Ševčíkův opis partitury z roku 1921, ze kterého dirigoval Talich, upravil problematické místo v Codě nově, bohužel špatným řešením. Do partitury také vepsal označení jednotlivých vět:

I. Moderato - Adagio (Smrt Ostapa)

II. Moderato - Allegro (Smrt Andrije)

III. Con moto - Andante Maestoso (Proroctví a smrt Tarase Buljby)

Je zajímavé, že Janáček zde omylem přehodil názvy prvních dvou vět. Takto velmi razantně zrevidovanou partituru zaslal 2. června 1927 do Hudební matice. ${ }^{66} \mathrm{O}$ den později napravil mýlku v označení vět. ${ }^{67}$

Během léta probíhaly přípravy, kdy těžko čitelná místa přepisoval korektor vydání Jindřich Máslo a Janáček je přehlížel. ${ }^{68}$ První kartáčové otisky nakladatelství zaslalo 7. října. $1927^{69}$, ale Janáček je požádal, aby korektury udělalo nakladatelství samo a zaslali mu až celek. ${ }^{70}$ Přesto Janáčkovi zasílali i nadále další archy ke korektuře. ${ }^{71}$ Janáček však řediteli Hudební matice Václavu Mikotovi napsal: „Na mne při korektuře moc nespoléhejte; prosím už toho Tarase dobře prohliželi. “72 Není divu, nebot skladatel byl tou dobou plně zaměstnán prací na opeře $Z$ mrtvého domu a následně prvním nastudováním a revizí Glagolské mše. $\mathrm{Z}$ tisku je patrné, že některé doplňky, především v dynamice, byly provedeny na poslední chvíli př́imo do matrice. Partitura vyšla tiskem v prosinci roku 1927, orchestrální hlasy pak byly pořízeny a rozmnoženy počátkem roku 1928. Zahraniční provedení tak přišla

63 Korespondenční lístek Hudební matice Leoši Janáčkovi z 22. 3. 1927 je uložen v JA MZM, sign. A 1246. Citováno z KLJ.

64 Dopis Leoše Janáčka Hudební matici z 28. 3. 1927 je uložen v JA MZM, sign. B 2411. Citováno z KLJ.

65 LÁNA, Oldřich. Leoš Janáček a Umělecká beseda (1920-1928). Druhá fáze spolupráce. Disertační práce, Ústav hudební vědy, Filozofická fakulta, Masarykova univerzita, Brno 2017, s. 92.

66 Kopie dopisu Leoše Janáčka Hudební matici z 2. června 1927je uložena v JA MZM, sign. D 1647. Citováno z KLJ.

67 Korespondenční lístek Leoše Janáčka Hudební Matici z 3. 6. 1927 je uložen v JA MZM, sign. A 6578. Citováno z KLJ.

68 Dopis Hudební matice Leoši Janáčkovi z 26. 7. 1927 je uložen v JA MZM, sign. D 558. Citováno z KLJ.

69 Dopis Hudební matice Leoši Janáčkovi z 9. 10. 1927 je uložen v JA MZM, sign. A 1247. Citováno z KLJ.

70 Dopis Leoše Janáčka Hudební matici z 9. 10. 1927 je uložen v JA MZM, sign. B 2410. Citováno z KLJ.

71 Dopisy Hudební matice Leoši Janáčkovi z 13. 10. a 5. 11. 1927 jsou uloženy v JA MZM, sign. A 1247, A1243. Citováno z KLJ.

72 Dopis Leoše Janáčka Hudební Matici z 19. 10. 1927 je uložen v JA MZM, sign. B 2419. Citováno z KLJ. 
na pořad dne až po skladatelově smrti, kdy Tarase Bulbu 16. ř́ijna 1928 provedl v Londýně Henry Wood (1869-1944).

Za zmínku stojí skladatelovo věnování skladby československé branné moci, které bylo uveřejněno v roce $1923 \mathrm{v}$ knize Československé armádě. Pozdrazy a vzkazy:

„Našemu vojsku.

Byl jsem presvědčen již dávno, že teplou melodii Smetanovou, mdlou něžností tónů Fibichových, svě̌esti rytmů Dvořákových ba ani věhlasem našich učenců, ani světlou památkou Komenského, ani mučednictvím Husovým - že tím vším svobody národa se nedosáhne.

Kulturni zbraně jsou záríivé, ale tupé.

$V$,Pohádce" pro cello a klavír kmital mi na mysli svit ostré ocele, $v$,sonáté pro housle a klavir z roku 1914 slyšel jsem v podrážděné mysli již - již jeji třeskot.

$V$, Rapsodii“ z r. 1915 plesal jsem vidině našich pluki̊ vstřic. Roku 1918 rozhlaholil se její hymnický motiv:

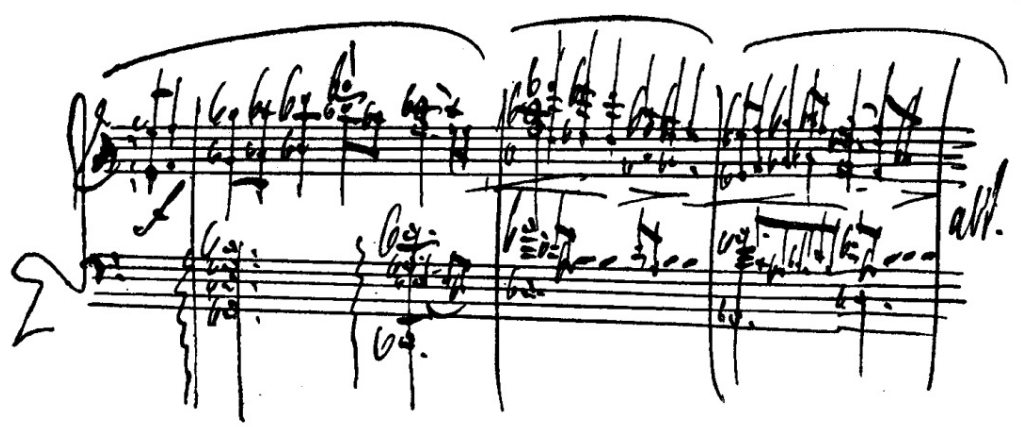

a když branné ochraně našeho národa tuto svou práci připisuji, je to z důvodu, že nechráníte nám jen naše pozemské statky, ale i celý náš myšlenkový svèt.

Brno, 15. zárí 1923“"73

Rapsodie Taras Bulba vznikla reakcí na politickou situaci 1. světové války a ze skladatelovy potřeby veřejně projevit své sympatie k ruskému národu a kultuře. Kvůli represím však byl Janáček nucen své rusofilství v prvních letech války veřejně neproklamovat. Přestože skladbu zkomponoval v roce 1915, pracoval na jejím finálním znění dvanáct let. Díky dochovaným pramenům můžeme doložit tento vývoj a jeho proměny v letech 1915, 1918, 1921, 1924 a 1927. Text je přípravnou studií ke kritické edici, která vyjde v př́ístím roce u nakladatelství Universal Edition ve Vídni.

73 Leoš Janáček: Našemu vojsku. In Československé armádě. Pozdravy a vzkazy. Československý vědecký ústav vojenský, Praha 1923, s. 61. 


\section{Bibliography}

\section{Sources}

ČERNUŠÁK, Gracian (šifra -k). Z brněnských koncertů. In: Lidové noviny, roč. XXIX (1921), č. 509 (11. 10.), s. 7.

Dopis brněnského Policejního ředitelství Ruskému kroužku ze dne 27. února 1925 je uložen v Moravském zemském archivu (dále MZA), fond Policejní ředitelství v Brně B 26, sign. 648, kart. 2522B.

GOGOL, Nikolaj Vasiljevič. Taras Bulba, Janáčkův exemplář knihy uložen v JA MZM, sign. JK 46.

JANÁČEK, Leoš. Našemu vojsku. In Československé armádě. Pozdravy a vzkazy. Československý vědecký ústav vojenský, Praha 1923, s. 61.

JANÁČEK, Leoš. Taras Bulba. Autograf skladby je uložen v JA MZM, sign. A 23.505, opis partitury Vojtěcha Ševčíka z roku 1915 je uložen tamtéž sign. A 33.789, nepoužité části původního Ševčíkova opisu s Janáčkovými úpravami jsou uloženy tamtéž, sign. A 33.789, opis partitury Vojtěcha Ševčíka a Václava Sedláčka z roku 1917 je uložen tamtéž, sign. A 49.313, opis partitury Vojtěcha Ševčíka z roku 1922 je uložen tamtéž, sign. A 39.739.

PITOUROVÁ, Antonie. Vzpominky na Leoše Janáčka. Strojopisný text je uložen v JA MZM, sign. D $187 \mathrm{LJ}$.

Protokol z domovní prohlídky z 27. 3. 1915 je uložen v MZA, fond Policejní ředitelství v Brně B 26, sign. 648, kart. 2522B.

Soudní rozhodnutí c. k. okresního soudu Brno město z 22. 1. 1916 je uložené v MZA, fond Policejní ředitelství v Brně B 26, sign. 648, kart. 2522B.

Stanovy Ruského kroužku v Brně, MZA, fond Policejní ředitelství v Brně B 26, sign. 648, kart. 2522B.

ZAHRÁDKA, Jiří a kolektiv (ed.): Korespondence Leoše Janáčka [online]. Brno 2016 [cit. 5-9-2017]

Zápisy ze schůzí Vydavatelské komise Hudební matice Umělecké besedy z 21. 12. 1923 je uložen v Literárním archivu Památníku národního písemnictví, fond Umělecká beseda, kart. B 31.

\section{Literature}

LÁNA, Oldřich. Leoš Janáček a Umělecká beseda (1920-1928). Druhá fáze spolupráce. Disertační práce, Ústav hudební vědy, Filozofická fakulta, Masarykova univerzita, Brno 2017.

PŘIBÁŇOVÁ, Svatava. K otázce vzniku Janáčkova Tarase Bulby. In Časopis morauského muzea, roč. XLIX (1964), s. 223-228.

PŘIBÁŇOVÁ, Svatava. O vzniku díla. In Leoš Janáček, Taras Bulba. Souborné kritické vydání, řada D, svazek 7, Supraphon-Bärenreiter, 1980, s. XI-XII.

SIMEONE, Nigel, TYRRELL, John, NĚMCOVÁ, Alena. Janáček's works. Clarendon Press, Oxford 1997.

TYRRELL, John. Janáček, Years of a Life. Volume II (1914-1928). The Lonely Blackbird. Faber and Faber, London 2007. 
VIČAR, Jan. Taras Bulba Leoše Janáčka. In Leoš Janáček světový a regionálni. Ostrava: Ostravská univerzita, 2008, s. 43-84.

VRBA, Přemysl. Ruský kroužek v Brně a Leoš Janáček. In: Slezský sbornik, roč. 58 (1960), č. 1, s. 71-85.

ZAHRÁDKA, Jiří. „Divadlo nesmí býti lidu komedi““ Leoš Janáček a Národni divadlo v Brně. Moravské zemské muzeum, Brno 2012.

Předložená práce vznikla za finančni podpory Ministerstva kultury v rámci institucionálního financováni na dlouhodobý koncepčni rozvoj výzkumné organizace Moravské zemské muzeum (DKRVO M000094862). 
